The Rangeland Journal, 2015, 37, 409-423

http://dx.doi.org/10.1071/RJ15010

\title{
Preventing weed spread: a survey of lifestyle and commercial landholders about Nassella trichotoma in the Northern Tablelands of New South Wales, Australia
}

\author{
A. Ruttledge ${ }^{\mathrm{A}, \mathrm{C}}$, R. D. B. Whalley ${ }^{\mathrm{A}}$, I. Reeve ${ }^{\mathrm{B}}$, D. A. Backhouse Band B. M. Sindel $^{\mathrm{A}}$ \\ ${ }^{A}$ School of Environmental and Rural Science, University of New England, Armidale, NSW 2351, Australia. \\ ${ }^{B}$ Institute for Rural Futures, University of New England, Armidale, NSW 2351, Australia. \\ ${ }^{\mathrm{C}}$ Corresponding author. Email: awruttledge@gmail.com
}

\begin{abstract}
Nassella trichotoma (Nees) Hack. ex Arechav. (common name, serrated tussock) occupies large areas of south-eastern Australia and has considerable scope for expansion in the Northern Tablelands of New South Wales. This highly invasive grass reduces pasture productivity and has the potential to severely affect the region's economy by decreasing the livestock carrying capacity of grazing land. Other potential consequences of this invasion include increased fuel loads and displacement of native plants, thereby threatening biodiversity. Rural property owners in the Northern Tablelands were sent a mail questionnaire that examined use of measures to prevent new outbreaks of the weed. The questionnaire was sent to professional farmers as well as lifestyle farmers (owners of rural residential blocks and hobby farms) and 271 responses were obtained (a response rate of 18\%). Key findings were respondents' limited capacity to detect $N$. trichotoma, and low adoption of precautions to control seed spread by livestock, vehicles and machinery. This was particularly the case among lifestyle farmers. There have been considerable recent changes to biosecurity governance arrangements in New South Wales, and now is an ideal time for regulators and information providers to consider how to foster regional communities' engagement in biosecurity, including the adoption of measures that have the capacity to curtail the spread of N. trichotoma.
\end{abstract}

Additional keywords: exotic species, governance, invasive plant controls, land management, pastoral industry, socio-ecological systems.

Received 29 January 2015, accepted 16 June 2015, published online 24 July 2015

\section{Introduction}

Nassella trichotoma is one of the 20 plant species originally listed as Weeds of National Significance in Australia (Thorp and Lynch 2000). Nassella trichotoma currently covers more than 2000000 ha of land in south-eastern Australia (Osmond et al. 2008). The grass has been said to account for a greater reduction in the carrying capacity of pasture than any other weed in Australia (Parsons and Cuthbertson 2001). Annual losses in production and control costs for Australian livestock farmers are in the order of $\$ 15000$ to $\$ 20000$ per person (McLaren et al. 2005). Consequences of invasion of native plant communities by $N$. trichotoma include increased fuel loads and reduced biodiversity through the displacement of native plants (Carr et al. 1992; NSW Scientific Committee 2003; Coutts-Smith and Downey 2006).

Because of its status as a Weed of National Significance, preventing new incursions of $N$. trichotoma is an important biosecurity priority for all Australian states and territories. Nassella trichotoma is listed in the Regional Weeds Strategy for the Northern Tablelands of New South Wales (NSW) as a
Class 3 Noxious Weed. Class 3 noxious weeds are plants that pose a potentially serious threat to primary production or the environment of the region, are not widely distributed in the area and are likely to spread in the area or to another area, posing a very high weed risk (Northern Inland Regional Weeds Strategy 2010).

The earliest herbarium specimen of $N$. trichotoma from the Northern Tablelands was collected at Hillgrove, south-east of Armidale in 1976 and is located in the NCW Beadle Herbarium at the University of New England (NE 34853) (Australian Virtual Herbarium 2015). By the beginning of the 21st century, it had become widespread in the Armidale district and a survey in 1999-2000 detected 123 infestations in an area of $20 \times 30 \mathrm{~km}$ to the east and south of Armidale (Cowan et al. 2007). A similar survey of the same area in 2003-2004 detected 165 infestations indicating that the weed was spreading rapidly (Cowan et al. 2007). This increase suggests that there is high risk that the weed could become widespread in the region unless control measures are generally applied across the landscape. Projections of climatic suitability under the current climate have indicated that conditions 
are optimal for its spread on the Northern Tablelands north to the Queensland border and beyond (Kriticos et al. 2004; Watt et al. 2011). It is, therefore, in the early spatio-temporal stages of invasion for non-indigenous plant species described by Theoharides and Dukes (2007) (transport, colonisation, establishment, and landscape spread). Nassella trichotoma has characteristics that suggest it has the potential to complete the invasion process in the Northern Tablelands of NSW. Key reasons for the very high risk of landscape spread are that $N$. trichotoma has an enormous capacity for seed production, and there are potentially numerous pathways by which the species' seeds can be dispersed over both small and large distances.

A mature tussock can produce up to 100000 seeds per annum (Healy 1945), which are naturally adapted for wind dispersal and can travel up to $1-4 \mathrm{~km} /$ day at moderate wind speeds (13.8-18 $\mathrm{km} / \mathrm{h}$ ) (Taylor 1987a, 1987b). Additional long-distance dispersal mechanisms documented for the species include floodwaters, river flow, gravel used in road building, vehicles (cars, trucks and graders), agricultural machinery, agricultural produce (white clover seed), horticultural activities (including contaminated soil attached to strawberry plants), and clothing (including trousers and socks) (Healy 1945). Moreover, the seed appears able to survive the passage through the digestive system of cattle and sheep (Healy 1945; Cook 1998). It is likely, therefore, that human activities, as well as the ecology of the species, are important in determining the rate and extent of the spread of $N$. trichotoma on the Northern Tablelands.

Biosecurity practices with the potential to mitigate spread of $N$. trichotoma seeds are often recommended in the online and printed materials produced for land managers. There is, however, no published information to assess whether landholders are heeding these messages. There is a concern that most of the materials produced to assist landholders with weed management do not reflect the differences among rural landholders, with lifestyle farmers co-existing with professional farmers in the rural landscape (Sindel et al. 2008; Coleman and Sindel 2011). Lifestyle farmers are often perceived to lack the necessary knowledge, motivation and ability to carry out effective pest control, and so may, therefore, fail to comply with the legal requirements (Ceddia et al. 2009; Klepeis et al. 2009; Bartel 2014). In the Northern Tablelands, lifestyle farmers have been criticised for being unable to correctly identify $N$. trichotoma, reluctant to use herbicide, and contributing to the decline of local weed management knowledge (Berney et al. 2012; Sindel et al. 2013).

A mail questionnaire was chosen as an appropriate method to obtain more information about the attitudes of different landholders to this emerging weed problem. This approach has several important advantages over other forms of survey (for example, telephone, online and in-person administered questionnaires). Mail surveys have low implementation needs (i.e. personnel and equipment), and are low cost, facilitating wide geographic coverage and larger samples. Weed infestation can be a sensitive issue, and mail surveys are unobtrusive, lending themselves to delicate topics. There was also a timing advantage, in that mail surveys can be disseminated and received in the mail within a short time after promotional activities designed to raise awareness and increase response rates (Bourque and Fielder 2003). Low response rates (usually $\sim 20 \%$ ) and non-sampling errors are the main disadvantages of mail surveys (Auld 1971; de Vaus 1995; Fink 2003).

Rural property owners in the Armidale district of the Northern Tablelands were sent a mail questionnaire that examined engagement in weed prevention management. This paper presents the results of the survey, and identifies differences between commercial livestock farmers and lifestyle farmers in terms of detection of $N$. trichotoma and engagement in prevention management. The results provide insights for regulators, researchers and educators working to contain the spread of $N$. trichotoma in the region, and have wider relevance for promoting biosecurity management on private land.

\section{Methods}

The Northern Tablelands of NSW are in the north-east of the state. The principal agricultural land uses are 'improved pasture' and 'native pasture,' and these pastures support a diverse range of grazing enterprises including fine wool, prime lamb and beef cattle production (Wilson and Lonergan 2013). The region supports some 2300 agricultural establishments, producing agricultural commodities valued at more than \$220 million (Alford et al. 2003). There are also large areas of public land within the region, including the Northern Tablelands Reserve system, which protects an area of 592570 ha (Office of Environment and Heritage 2012). In addition, there has recently been a large increase in the number of people who work in the regional cities of the region but live on small landholdings in the district (Sindel et al. 2013).

An unaddressed mail service provided by Australia Post was used to distribute a self-completion questionnaire (Appendix 1) to 1489 letterboxes along rural roads in the Armidale district, during July and August 2009. Respondents were asked to provide information on the main land use of their property, knowledge of serrated tussock, and their use of nominated prevention management tactics. For each question, the person was asked to select from a list of response categories (see Appendix 1).

Various techniques were employed to counter the disadvantages of mail surveys as described above, including the careful design and testing of the questionnaire. The development of the questionnaire was informed by a review of the scientific literature and extension materials designed for landholders (for example, CRC for Australian Weed Management 2003; Michelmore et al. 2003; Department of Primary Industries 2004; Ayers and Leech 2006; Osmond et al. 2008). A draft version of the questionnaire was circulated among weed scientists, extension and enforcement agents, and local landholders, as well as the Human Research Ethics Committee at the University of New England (Human Research Ethics Committee Approval Number: HE09/072). Further steps to minimise these errors included: an accompanying cover letter (see Appendix 1) to inform the recipients of the purpose and objectives of the survey so as to build trust and allay fears (for example, over confidentiality); provision of a self-addressed postage-paid envelope to make returning the completed survey easier; and most importantly, media promotion in the weeks preceding the survey - the research was publicised in several of the major regional newspapers and on $\mathrm{ABC}$ Radio, New England North West. 
An electronic version of each returned survey was created (FileMaker Pro7; FileMaker Inc., Santa Clara, CA, USA). Tick box responses were coded numerically. For example, 'Yes' was coded ' 1 ' and 'No' was coded ' 2 '. The data were then exported (as a tab-separated text file) into Microsoft Excel, and then imported into the software used to analyse the data (PASW Statistics 20; IBM Corp., Armonk, NY, USA). In the imported file, the database fields became the variables.

To compare these two main landholder groups in the statistical analysis, responses were categorised as either: (1) rural lifestyle (RL), a group comprised of the respondents who owned a hobby farm or rural residential block (see Appendix 1, Question 1, Section 1); or (2) commercial livestock farmers (CLF), a group containing the responses received from owner/ operators of commercial livestock farming properties (including mixed cropping/livestock farms). The two groups were comparable in terms of the number of respondents in each (140 RL and $125 \mathrm{CLF}$ ), and moreover the approach used to analyse the data involved non-parametric tests, robust with respect to unequal sample sizes of the study groups. For each question, the responses of the two groups were examined with a contingency table in which the columns were the two landholder-types (RL and CLF), and the rows were the response categories. All tables were $2 \times 2$ tables and Fisher's exact test was used to test independence of factors. In the $2 \times 2$ tables, the researchers' expectations can be given expression as the alternative hypothesis to the null hypothesis, which in turn implies a directional association. For example, lifestyle farmers are associated with lower proportions able to identify weeds. In $2 \times 2$ tables where prior knowledge suggested a directional association, the one-tailed $P$-value was chosen for interpretation. A $P$-value for the test statistic of less than 0.01 was generally interpreted as justification for rejecting the null hypothesis that the nature of the response to a question was independent of landholder type. For simplicity of description throughout the results reported below, we use the term 'association' rather than 'non-independence of factors'.

As all questions resulted in nominal variables, (i.e. the categories did not imply any particular rank order), tests of linear association were not considered.

\section{Results and discussion}

Postal survey response

Two-hundred and seventy-one (271) completed responses were received, representing a response rate of $18.2 \%$. Responses were received from Armidale, Dorrigo, Guyra, Hillgrove, Invergowrie,
Kelly's Plains, Tilbuster and Wollomombi, all within the Armidale district. These included owner/managers of 115 commercial livestock farms, 86 hobby farms, 54 rural residential properties, 10 mixed farms (cropping and livestock), two cropping properties, and one commercial horticulture operation. There were also several respondents who used the 'Other' category to indicate that their property was a dog-boarding kennel, a horse stud and a wildlife corridor.

Based on this distribution of responses, most were either livestock farmers or owners of 'RL' properties (hobby farmers and owners of rural residences). As described above in the Methods section, these 265 respondents were categorised into two groups of similar size: (1) RL group, comprising 140 responses received from hobby farmers and owners of rural residences; and (2) CLF group, containing 125 responses (including the 'mixed' farms - cropping and livestock). The remaining six completed questionnaires (cropping properties, commercial horticulture operation, dog-boarding kennel, wildlife corridor and the horse stud) were excluded from the analysis.

\section{Weed identification and early detection}

There was an association between ability to identify N. trichotoma and landholder type (Table 1), with more than five times the proportion of the RL group indicating that they were NOT confident in their ability to identify the species (RL $48.6 \%$ vs CLF 9.7\%). Similarly, the proportion who did not know whether N. trichotoma had been detected on their land (Table 2) was over seven times higher in the RL group (RL 30\% vs CLF 4\%). Based on this result, it would be justifiable for resources to be spent on teaching hobby farmers and owners of rural residential blocks to identify $N$. trichotoma. That almost the entire CLF group had learnt to identify the weed indicates that the materials and/or approaches used to teach landholders weed identification skills are more oriented towards commercial farmers than lifestyle farmers. This confirms the suggestion by other authors (Sindel et al. 2008; Coleman and Sindel 2011), that materials produced to assist landholders with weed management often do not reflect the differences among rural landholders.

The tests of association were significant for both weed inspection (Table 3) and early identification of potential grass weeds (Table 4). Although the majority of both groups did indicate that they inspected part or all of their property for weeds on a regular basis, $15 \%$ of the RL group did not participate in any regular weed inspection activities, relative to $4.8 \%$ of the CLF group. In regards to early detection of grass weeds, the contrast was more marked, with $41.7 \%$ of the RL group not taking steps to

Table 1. Ability to identify Nassella trichotoma from a survey of landholders in the Armidale district: comparison of two landholder types, rural lifestyle (RL) and commercial livestock farmer (CLF)

\begin{tabular}{|c|c|c|c|c|c|}
\hline \multirow[t]{2}{*}{ Statement } & & \multirow[t]{2}{*}{ Response } & \multicolumn{3}{|c|}{ Landholder types } \\
\hline & & & RL & CLF & Total \\
\hline $\begin{array}{l}\text { Respondent is confident } \\
\text { they are able to identify }\end{array}$ & & Yes & $51.4 \%$ & $90.3 \%$ & $69.7 \%$ \\
\hline serrated tussock & & No & $48.6 \%$ & $9.7 \%$ & $30.3 \%$ \\
\hline Total count $(n)$ & & - & 140 & 124 & 264 \\
\hline & Exact Sig. (2-sided) & Exact Sig. (1-sided) & & & \\
\hline Fisher's exact test & $P<0.0005$ & $P<0.0005$ & & & \\
\hline
\end{tabular}


Table 2. Knowledge of property Nassella trichotoma infestation status from a survey of landholders in the Armidale district: comparison of two landholder types, rural lifestyle (RL) and commercial livestock farmer (CLF)

\begin{tabular}{|c|c|c|c|c|c|}
\hline \multirow[t]{2}{*}{ Statement } & & \multirow[t]{2}{*}{ Response } & \multicolumn{3}{|c|}{ Landholder types } \\
\hline & & & RL & CLF & Total \\
\hline $\begin{array}{l}\text { Respondent knows if serrated } \\
\text { tussock has been detected on }\end{array}$ & & Yes & $70.0 \%$ & $96.0 \%$ & $82.2 \%$ \\
\hline their property & & No & $30.0 \%$ & $4.0 \%$ & $17.8 \%$ \\
\hline Total count $(n)$ & & - & 140 & 124 & 264 \\
\hline Fisher's exact test & $\begin{array}{l}\text { Exact Sig. (2-sided) } \\
\qquad P<0.0005\end{array}$ & $\begin{array}{l}\text { Exact Sig. (1-sided) } \\
\qquad P<0.0005\end{array}$ & & & \\
\hline
\end{tabular}

Table 3. Involvement in property weed inspection, from a survey of landholders in the Armidale district: comparison of two landholder types, rural lifestyle (RL) and commercial livestock farmer (CLF)

\begin{tabular}{|c|c|c|c|c|c|}
\hline \multirow[t]{2}{*}{ Statement } & & \multirow[t]{2}{*}{ Response } & \multicolumn{3}{|c|}{ Landholder types } \\
\hline & & & RL & CLF & Total \\
\hline $\begin{array}{l}\text { Respondent conducts } \\
\text { regular weed inspections }\end{array}$ & & Yes & $85.0 \%$ & $95.2 \%$ & $89.8 \%$ \\
\hline on their property & & No & $15.0 \%$ & $4.8 \%$ & $10.2 \%$ \\
\hline Total count $(n)$ & & - & 140 & 125 & 265 \\
\hline & Exact Sig. (2-sided) & Exact Sig. (1-sided) & & & \\
\hline Fisher's exact test & $P=0.007$ & $P=0.005$ & & & \\
\hline
\end{tabular}

Table 4. Involvement in early detection of potential new grass weeds, from a survey of landholders in the Armidale district: comparison of two landholder types, rural lifestyle (RL) and commercial livestock farmer (CLF)

\begin{tabular}{|c|c|c|c|c|c|}
\hline \multirow[t]{2}{*}{ Statement } & & \multirow[t]{2}{*}{ Response } & \multicolumn{3}{|c|}{ Landholder types } \\
\hline & & & RL & CLF & Total \\
\hline $\begin{array}{l}\text { Unknown grass species are } \\
\text { identified early before they }\end{array}$ & & Yes & $58.3 \%$ & $88.3 \%$ & $72.9 \%$ \\
\hline become widespread & & No & $41.7 \%$ & $11.7 \%$ & $27.1 \%$ \\
\hline Total count $(n)$ & & - & 127 & 120 & 247 \\
\hline Fisher's exact test & $\begin{array}{l}\text { Exact Sig. (2-sided) } \\
\qquad P<0.0005\end{array}$ & $\begin{array}{l}\text { Exact Sig. (1-sided) } \\
\quad P<0.0005\end{array}$ & & & \\
\hline
\end{tabular}

identify new/unfamiliar species of grass - this was more than three times higher than the proportion of the CLF group (11.7\%).

These results are consistent with the concern expressed in the literature; that lifestyle farmers often lack the necessary knowledge, motivation and ability to carry out effective pest control, and so may, therefore, contribute to the decline of local weed management, as well as failing to comply with their legal requirements as landholders (Ceddia et al. 2009; Klepeis et al. 2009; Berney et al. 2012; Sindel et al. 2013; Bartel 2014). Although the size of rural residential and lifestyle blocks tend to be much smaller than commercial livestock farms, because each infested agent increases the $N$. trichotoma invasion risk for a large portion of the landscape (Coutts et al. 2013), it is essential that all rural land managers possess the knowledge and motivation to detect and control the species. On a positive note, Low Choy and Harding (2008) have reported that lifestyle farmers have the potential and desire to improve their knowledge of weed spread, detection and control. To exploit this potential, extension efforts must address the needs of both lifestyle farmers and professional farmers (Vanclay 2004).

\section{Reducing seed spread from on-farm sources}

Landholders who identified that $N$. trichotoma had been detected on their land (48.1\% of 264 landholders) were asked to indicate the methods that they used to prevent seed spreading from these infestations. There was no association between landholder group and use of methods to curb livestock-mediated movement (Table 5), methods to prevent machinery and vehicles spreading $N$. trichotoma seeds (Table 6), or measures to control the source (s) of $N$. trichotoma seeds (Table 7). For mitigation of wind dispersal (Table 8), the response was significantly associated with group membership (RL 27.5\% non-adoption vs CLF 5.3\%).

An explanation for the low adoption of the measures oriented towards preventing $N$. trichotoma seed spread by livestock ( $21.3 \%$ adoption), and vehicles/machinery (32.3\% adoption) is that these methods were considered unnecessary because most respondents took measures to remove the seed supply (i.e. by not letting plants set seed). An alternative explanation is that the potential of these factors (livestock, machinery and vehicles) to spread the seeds of $N$. trichotoma is not well recognised, unlike the potential for dispersal by wind. 
Table 5. Use of methods to prevent Nassella trichotoma seed spread by livestock on properties where the weed has been detected, from a survey of landholders in the Armidale district: comparison of two landholder types, rural lifestyle (RL) and commercial livestock farmer (CLF)

\begin{tabular}{|c|c|c|c|c|c|}
\hline \multirow[t]{2}{*}{ Statement } & & \multirow[t]{2}{*}{ Response } & \multicolumn{3}{|c|}{ Landholder types } \\
\hline & & & RL & CLF & Total \\
\hline $\begin{array}{l}\text { Use of methods to reduce } \\
\text { serrated tussock seed spread }\end{array}$ & & Yes & $19.6 \%$ & $22.4 \%$ & $21.3 \%$ \\
\hline by livestock ${ }^{\mathrm{A}}$ & & No & $80.4 \%$ & $77.6 \%$ & $78.7 \%$ \\
\hline Total counts $(n)$ & & - & 51 & 76 & 127 \\
\hline & Exact Sig. (2-sided) & Exact Sig. (1-sided) & & & \\
\hline Fisher's exact test & $P=0.826$ & $P=0.443$ & & & \\
\hline
\end{tabular}

${ }^{\mathrm{A}}$ Methods included shearing sheep to remove seeds in fleece if sheep had grazed $N$. trichotoma when in flower, keeping stock out of areas where $N$. trichotoma was in flower (stock exclusion), and putting livestock in holding yards if they had grazed areas where $N$. trichotoma was in flower (quarantine).

Table 6. Use of methods to prevent Nassella trichotoma seed-spread by vehicles and machinery on properties where the weed has been detected, from a survey of landholders in the Armidale district: comparison of two landholder types, rural lifestyle (RL) and commercial livestock farmer (CLF)

\begin{tabular}{|c|c|c|c|c|c|}
\hline \multirow[t]{2}{*}{ Statement } & & \multirow[t]{2}{*}{ Response } & \multicolumn{3}{|c|}{ Landholder types } \\
\hline & & & RL & CLF & Total \\
\hline $\begin{array}{l}\text { Use of methods to reduce } \\
\text { serrated tussock seed spread by }\end{array}$ & & Yes & $27.5 \%$ & $35.5 \%$ & $32.3 \%$ \\
\hline vehicles and machinery ${ }^{\mathrm{A}}$ & & No & $72.5 \%$ & $64.5 \%$ & $67.7 \%$ \\
\hline Total count $(n)$ & & - & 51 & 76 & 127 \\
\hline & Exact Sig. (2-sided) & Exact Sig. (1-sided) & & & \\
\hline Fisher's exact test & $P=0.439$ & $P=0.224$ & & & \\
\hline
\end{tabular}

Table 7. Use of methods to prevent Nassella trichotoma seed supply from infestations of the weed, from a survey of landholders in the Armidale district: comparison of two landholder types, rural lifestyle (RL) and commercial livestock farmer (CLF)

\begin{tabular}{|c|c|c|c|c|c|}
\hline \multirow[t]{2}{*}{ Statement } & & \multirow[t]{2}{*}{ Response } & \multicolumn{3}{|c|}{ Landholder types } \\
\hline & & & RL & CLF & Total \\
\hline $\begin{array}{l}\text { Use of methods to reduce serrated } \\
\text { tussock seed spread by controlling }\end{array}$ & & Yes & $94.1 \%$ & $100.0 \%$ & $97.6 \%$ \\
\hline the sources of seeds ${ }^{\mathrm{A}}$ & & No & $5.9 \%$ & $0.0 \%$ & $2.4 \%$ \\
\hline Total count $(n)$ & & - & 51 & 76 & 127 \\
\hline Fisher's exact test & $\begin{array}{c}\text { Exact Sig. (2-sided) } \\
P=0.062\end{array}$ & $\begin{array}{c}\text { Exact Sig. (1-sided) } \\
P=0.062\end{array}$ & & & \\
\hline
\end{tabular}

${ }^{\mathrm{A}}$ Methods included controlling the plants before seed set or removing and disposing of seed heads.

When survey participants were asked to indicate the pathway suspected to have been responsible for introducing $N$. trichotoma infestation of their property (Table 9 and Table 10), a higher proportion of the RL group did not indicate a pathway, but chose to select the 'unknown' response (selected by $37.5 \%$ of the RL group, $18.4 \%$ of the CLF group, and $25.8 \%$ overall). This difference between the RL and the CLF group was significant if the threshold was $P<0.05$ but not if it was $P<0.01$. The CLF group demonstrated significantly better awareness of the risk of weed-seed introduction via natural and human-controlled pathways including wind, wildlife, product contamination, livestock, vehicles and machinery. Nassella trichotoma is naturally adapted for wind dispersal, and this pathway of seed dispersal was the most frequently nominated mode of introduction (RL 53.3\%, CLF $66.1 \%$, and overall $62.0 \%$ ). Human-mediated pathways were nominated by a small percentage of respondents [product contamination $3.3 \%$ of total), livestock (3.3\% of total), and vehicles and machinery (4.1\% of total)]. These results are consistent with the findings of research into perceptions and beliefs about weed management; farmers tend to overlook risks associated with management, believing introduction of new weeds to be inevitable - being 
Table 8. Use of methods to limit Nassella trichotoma seed spread by wind, from a survey of landholders in the Armidale district: comparison of two landholder types, rural lifestyle (RL) and commercial livestock farmer (CLF)

\begin{tabular}{|c|c|c|c|c|c|}
\hline \multirow[t]{2}{*}{ Statement } & & \multirow[t]{2}{*}{ Response } & \multicolumn{3}{|c|}{ Landholder types } \\
\hline & & & RL & CLF & Total \\
\hline $\begin{array}{l}\text { Use of methods to reduce } \\
\text { serrated tussock seed spread }\end{array}$ & & Yes & $72.5 \%$ & $94.7 \%$ & $85.8 \%$ \\
\hline by wind ${ }^{\mathrm{A}}$ & & No & $27.5 \%$ & $5.3 \%$ & $14.2 \%$ \\
\hline Total count $(n)$ & & - & 51 & 76 & 127 \\
\hline Fisher's exact test & $\begin{array}{c}\text { Exact Sig. (2-sided) } \\
\qquad P=0.001\end{array}$ & $\begin{array}{l}\text { Exact Sig. (1-sided) } \\
\qquad P=0.001\end{array}$ & & & \\
\hline
\end{tabular}

${ }^{\mathrm{A}}$ Methods included creating wind barriers (tree rows or mesh fences), and inspecting land downwind of infestations for N. trichotoma plants.

Table 9. Respondents' nomination of pathway(s) they believed to be responsible for introduction of Nassella trichotoma to their property

Question only answered by respondents who owned/managed land where the weed has been detected. Results of a survey of landholders in the Armidale district: comparison of two landholder types, rural lifestyle (RL) and commercial livestock farmer (CLF)

\begin{tabular}{|c|c|c|c|c|}
\hline \multirow[t]{2}{*}{ Statement } & \multirow[t]{2}{*}{ Response } & \multicolumn{3}{|c|}{ Landholder types } \\
\hline & & RL & CLF & Total \\
\hline Pathway held responsible & Unknown & $37.5 \%$ & $18.4 \%$ & $25.8 \%$ \\
\hline $\begin{array}{l}\text { for introduction of serrated } \\
\text { tussock seed to the property }\end{array}$ & Pathway selected ${ }^{\mathrm{A}}$ & $62.5 \%$ & $81.6 \%$ & $74.2 \%$ \\
\hline Total count $(n)$ & & 48 & 76 & 124 \\
\hline & Exact Sig. (2-sided) & Exact Sig. (1-sided) & & \\
\hline Fisher's exact test & $P=0.022$ & $P=0.016$ & & \\
\hline
\end{tabular}

Table 10. Of the respondents that nominated pathway(s) they believed to be responsible for introduction of Nassella trichotoma to their property, the proportion who selected 'wind' versus another suspected pathway

Question only answered by respondents who owned/managed land where the weed has been detected. Results of a survey of landholders in the Armidale district: comparison of two landholder types, rural lifestyle (RL) and commercial livestock farmer (CLF)

\begin{tabular}{|c|c|c|c|c|}
\hline \multirow[t]{2}{*}{ Statement } & \multirow[t]{2}{*}{ Response } & \multicolumn{3}{|c|}{ Landholder types } \\
\hline & & RL & CLF & Total \\
\hline $\begin{array}{l}\text { Pathway held responsible } \\
\text { for introduction of serrated }\end{array}$ & Wind & $53.3 \%$ & $66.1 \%$ & $62.0 \%$ \\
\hline tussock seed to the property & Other selection ${ }^{\mathrm{A}}$ & $46.7 \%$ & $33.9 \%$ & $38.0 \%$ \\
\hline Total count $(n)$ & - & 30 & 62 & 92 \\
\hline & Exact Sig. (2-sided) & Exact Sig. (1-sided) & & \\
\hline Fisher's exact test & $P=0.259$ & $P=0.169$ & & \\
\hline
\end{tabular}

${ }^{\mathrm{A} C o m p r i s i n g}$ wildlife, product contamination, livestock, vehicles and machinery, unknown and 'other'.

caused principally by natural processes (Wilson et al. 2008, 2009).

\section{Reducing seed spread from off-farm sources}

Respondents were provided with a list of strategies aimed at preventing weed seeds from being introduced to the property from off-farm sources. Tests of association were significant for all three types of weed-seed entry pathways: vehicles and machinery (Table 11), contamination of purchased plant materials including seed and fodder (Table 12), and newly purchased livestock (Table 13). In all cases, the proportion of the CLF group who had adopted the listed strategies was more than twice that of the RL group.
In terms of the purchase of livestock, seed and fodder, the relatively low adoption of weed spread prevention measures by the RL group relative to the CLF group can be understood in the context of their property type, because purchasing these products would not be a regular occurrence, unlike on commercial livestock farms. With respect to vehicles and machinery, however, all rural properties would have regular vehicle traffic, suggesting that the risk of this pathway to introduce new weed seeds may not be appreciated by over $70 \%$ of lifestyle farmers. This was not unique to the RL group - a quarter of respondents in the CLF group were also not using the methods aimed at curbing spread mediated by vehicles and machinery. Every rural property is at risk of this mode of spread, considering that travel in passenger vehicles is a regular part of everyday life in rural parts 
Table 11. Landholders' use of methods to prevent vehicles and machinery from introducing weed seeds to the property, from a survey of landholders in the Armidale district: comparison of two landholder types, rural lifestyle (RL) and commercial livestock farmer (CLF)

\begin{tabular}{|c|c|c|c|c|c|}
\hline \multirow[t]{2}{*}{ Statement } & & \multirow[t]{2}{*}{ Response } & \multicolumn{3}{|c|}{ Landholder types } \\
\hline & & & RL & CLF & Total \\
\hline $\begin{array}{l}\text { Use of methods to prevent vehicles } \\
\text { and machinery from introducing }\end{array}$ & & Yes & $27.9 \%$ & $74.4 \%$ & $49.8 \%$ \\
\hline weed seeds to the property ${ }^{\mathrm{A}}$ & & No & $72.1 \%$ & $25.6 \%$ & $50.2 \%$ \\
\hline Total counts $(n)$ & & Count $(n)$ & 140 & 125 & 265 \\
\hline & Exact Sig. (2-sided) & Exact Sig. (1-sided) & & & \\
\hline Fisher's exact test & $P<0.0005$ & $P<0.0005$ & & & \\
\hline
\end{tabular}

$\overline{{ }^{\mathrm{A}} \text { Methods included refusing entry to vehicles and machinery used in locations known to contain } N \text {. trichotoma, cleaning vehicles and }}$ machinery from off-farm likely to carry weed seeds, and careful selection of machinery contractors based on their weed hygiene practices.

Table 12. Landholders' use of methods to prevent weed seeds entering the property in contaminated plant products, from a survey of landholders in the Armidale district: comparison of two landholder types, rural lifestyle (RL) and commercial livestock farmer (CLF)

\begin{tabular}{|c|c|c|c|c|c|}
\hline \multirow{2}{*}{ Statement } & & \multirow[t]{2}{*}{ Response } & \multicolumn{3}{|c|}{ Landholder types } \\
\hline & & & RL & CLF & Total \\
\hline $\begin{array}{l}\text { Use of methods to prevent contaminated } \\
\text { plant products from introducing }\end{array}$ & & Yes & $33.6 \%$ & $86.4 \%$ & $58.5 \%$ \\
\hline weed seeds to the property ${ }^{\mathrm{A}}$ & & No & $66.9 \%$ & $13.6 \%$ & $41.5 \%$ \\
\hline Total count $(n)$ & & - & 140 & 125 & 265 \\
\hline & Exact Sig. (2-sided) & Exact Sig. (1-sided) & & & \\
\hline Fisher's exact test & $P<0.0005$ & $P<0.0005$ & & & \\
\hline
\end{tabular}

$\overline{{ }^{\mathrm{A}} \text { Tactics included feeding stock in weed-patrolled areas, and only purchasing certified seed (i.e. with guaranteed low weed-seed }}$ content).

Table 13. Landholders' use of methods to prevent livestock introducing weed seeds to the property, from a survey of landholders in the Armidale district: comparison of two landholder types, rural lifestyle (RL) and commercial livestock farmer (CLF)

\begin{tabular}{|c|c|c|c|c|c|}
\hline \multirow[t]{2}{*}{ Statement } & & \multirow[t]{2}{*}{ Response } & \multicolumn{3}{|c|}{ Landholder types } \\
\hline & & & RL & CLF & Total \\
\hline $\begin{array}{l}\text { Use of methods to prevent newly } \\
\text { purchased livestock from introducing }\end{array}$ & & Yes & $10.7 \%$ & $38.4 \%$ & $23.8 \%$ \\
\hline weed seeds to the property ${ }^{\mathrm{A}}$ & & No & $89.3 \%$ & $61.6 \%$ & $76.2 \%$ \\
\hline Total counts $(n)$ & & - & 140 & 125 & 265 \\
\hline Fishar's oy rett tact & Exact Sig. (2-sided) & Exact Sig. (1-sided) & & & \\
\hline
\end{tabular}

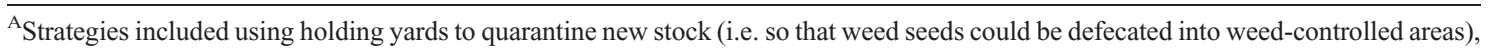
and shearing any newly bought sheep where there was potential for their fleece to contain weed seeds.

of Australia. Passenger vehicles have the demonstrated capacity to transport a variety of weed seeds, including grasses, over considerable distances (Wace 1977; Lonsdale and Lane 1990, 1994). Landholders, who are unaware of this potential, would fail to appreciate the potential advantage to their property of reducing weed-seed loads by implementing basic vehiclehygiene practices.

In the CLF group, the use of livestock-oriented precautions (38.4\% adoption) was low relative to precautions against plantcontaminated materials ( $86.4 \%$ adoption). Hogan and Phillips (2011) have reviewed the literature on weed-seed transmission by livestock. They found that weed seeds are readily translocated by livestock, including by attachment to their coats, consumption, and vehicles used for transporting them. Australia, with its extensive grazing practices and magnitude of livestock movement, is at particular risk of widespread weed-seed dissemination by livestock, and this issue needs to be addressed at local, national and international levels (Hogan and Phillips 2011).

The concept of a withholding period of 7-10 days, to allow time for excretion of weed seeds ingested by livestock, is a common principle in weed-related extension advice, and appears to be based on the literature (Stanton et al. 2003). The seeds of $N$. trichotoma have been reported to survive passage through the digestive system of cattle (Healy 1945) and sheep (Cook 1998). However, under natural circumstances, the lack of preference by livestock for the inflorescences would render it unlikely that livestock would consume large amounts of $N$. trichotoma seeds. Consumption of grass seeds by ruminants has been shown to 
represent a low risk for spread, except potentially in fresh manure, with digestion time and duration buried in manure reducing seed viability (Janzen 1984; Andrews 1995; Gardener et al. 2003).

Epizoochory (transport of seeds attached to the outside of vertebrate animals) appears to have greater potential for longdistance dispersal of grass seeds relative to endozoochory (transport of seeds consumed by grazing animals), including the grass Stipa krylovii, which is from a closely related genus to N. trichotoma (Bläß et al. 2010). Adherence in sheep wool has been found to transport seeds of the closely related grass Nassella neesiana (Chilean needle grass) (Gardener et al. 2003), and this risk has not been quantified for $N$. trichotoma.

The potential for $N$. trichotoma to spread over long distances through the movement of machinery, vehicles and livestock has been known for almost 70 years (Healy 1945). However, based on the results of this survey, a lot of work remains to be done in terms of mediating the risk potential of these human-mediated pathways to spread $N$. trichotoma. In a recent survey, Australian scientists and extension officers rated human-related dispersal pathways (weed-seed contamination of vehicles, machinery, livestock and other transported materials) as being the most important means of weed-spread. The majority of those surveyed were of the opinion that human-mediated dispersal was being improperly managed, advocating more research (specific to the Australian context), awareness raising, and regulation including industry-specific codes of practice, enforcement and fines (Coleman et al. 2011). Before considering the harsher options of enforcement, it is suggested that voluntary engagement in prevention management is facilitated by building land-holders' confidence in their ability to prevent new weed infestations. An important aspect of promoting use of voluntary practices will be to show rural landholders that there is a demonstrably high risk (for example, of viable weed-seed translocation), and the cost-benefit scenario strongly favours implementation (Knowler and Bradshaw 2007; Greiner et al. 2009).

\section{Implications for biosecurity}

For over a decade, $N$. trichotoma has been the target of sustained control and extension efforts by local organisations including the Northern Inland Weeds Advisory Committee, Southern New England Landcare, and the New England Weeds Authority. However, these survey results indicate that many landholders, particularly lifestyle farmers but also some professional livestock farmers, need further encouragement to adopt on-farm biosecurity measures that could mitigate the impact of $N$. trichotoma and other noxious weeds.

In the light of recent changes to biosecurity arrangements in NSW, now is an ideal time for decision-makers to reconsider how they can engage landholders in the delivery of biosecurity outcomes. Under the Local Land Services Act, (which became operational in January 2014), supported by the Local Land Services Regulation 2014, local decision-making is the responsibility of the newly established Local Land Services (LLS). In addition to these changes, the NSW Government has recently released several important strategic documents including the NSW Biosecurity Strategy (2013-2021), and a draft Biosecurity Framework for NSW. This latter document will inform the future development of a NSW Biosecurity Act, will wholly or partly replace 14 pieces of existing legislation [including the Noxious Weeds Act 1993 and the Local Land Services Act 2013 (Part 10-Pests)], to form one piece of cohesive, innovative legislation, which will support the nationally agreed principle that biosecurity is a shared responsibility (NSW Department of Primary Industry 2014).

Insights from the literature on natural resource governance (Marshall 2008, 2009, 2010, 2011; Pannell and Wilkinson 2009; Marshall and Stafford Smith 2010; Bartel 2014) can provide valuable insights for successfully implementing these new biosecurity arrangements. Laws that are misaligned with local conditions, local knowledge, and local priorities can compromise the social agreement necessary for regulatory success. To be consistent with the nationally agreed principle that biosecurity is a shared responsibility, LLS will need to effectively engage the diverse populations in the large areas for which they are responsible. It is suggested that the efficacy of LLS would be strengthened by research that examines how landholders perceive the new biosecurity arrangements for NSW, specifically in terms of the capacity to engage local landholders in delivering biosecurity outcomes.

\section{Conclusions}

Nassella trichotoma has considerable scope for expansion in the Northern Tablelands of NSW. The weed has the potential to severely affect the region's economy by decreasing the livestockcarrying capacity of grazing land. Other potential consequences of $N$. trichotoma invasion include increased fuel loads and the displacement of native plants.

A key finding of this survey of rural landholders in the Northern Tablelands was that many lifestyle farmers lack the skills to detect $N$. trichotoma and do not know if their land contains an infestation. Measures to reduce introduction of weedseed spread by livestock, vehicles and machinery were often not being used. Possible reasons for non-adoption of prevention measures include a perception that livestock, vehicles and machinery represent a low risk of introducing new seeds and, therefore, the costs (including effort) of implementing prevention measures are not worthwhile.

The results of this survey provide insights for decision-makers tasked with containing the spread of $N$. trichotoma and other invasive plant species, and have wider relevance for promoting biosecurity management on rural properties. Considering recent changes to biosecurity arrangements in NSW, now is an opportune time for regional weed authorities to re-examine how best to manage invasive plants in the context of the rural landscape. Rather than focusing on control of existing populations, it is suggested that the development of regional weed strategies is centred upon prevention, starting with disrupting the invasion process through controlling dispersal pathways, and so precluding damaging ecological and economic consequences of habitat invasion. Because the success of such an approach will be underpinned by the coordinated effort of all stakeholders, a detailed consultative process and further ecological-social research would be valuable in ensuring that biosecurity arrangements effectively encompass the diversity of rural landholders, fostering engagement in weed prevention on both farming and non-farming rural properties. 


\section{Acknowledgements}

This research was funded by Australian Wool Innovation, as part of a postgraduate research project. We wish to acknowledge the assistance of Michael Coleman and Christine Fyfe with the creation and maintenance of the FileMaker Pro7 database. We would also like to thank the administrative staff of the Department of Agronomy and Soil Science (University of New England) for assisting with the survey mail-out. We are grateful to those who provided feedback on the construction of the survey. Finally, our sincere thanks go to the many respondents who completed the questionnaires.

\section{References}

Alford, A. R., Griffith, G. R., and Davies, B. L. (2003). 'Livestock Farming Systems in the Northern Tablelands of NSW: An Economic Analysis.' Economic Research Report No. 12. (NSW Agriculture: Orange, NSW.)

Andrews, T. S. (1995). Dispersal of seeds of giant Sporobolus spp. after ingestion by grazing cattle. Australian Journal of Experimental Agriculture 35, 353-356. doi:10.1071/EA9950353

Auld, B. A. (1971). Survey of weed problems of the North Coast of New South Wales. Tropical Grasslands 5, 27-30.

Australian Virtual Herbarium (2015). Available at: http://avh.chah.org.au/ (accessed 4 May 2015).

Ayers, L., and Leech, F. (2006). 'Serrated Tussock - Identification and Control. Primefact 44.' (NSW Department of Primary Industries: Orange, NSW.)

Bartel, R. (2014). Vernacular knowledge and environmental law: cause and cure for regulatory failure. Local Environment: The International Journal of Justice and Sustainability 19, 891-914. doi:10.1080/ 13549839.2013.798636

Berney, P. J., Sindel, B. M., Coleman, M. J., Marshall, G. R., Reeve, I. J., and Kristiansen, P. E. (2012). Improving regional adoption of weed control: a case study. In: 'Developing Solutions to Evolving Weed Problems. Proceedings of the 18th Australasian Weeds Conference'. (Ed. V. Eldershaw.) pp. 170-173. (Weed Science Society of Victoria Inc.: Melbourne.)

Bläß, C., Ronnenberg, K., Tackenberg, O., Hensen, I., and Wesche, K. (2010). The relative importance of different seed dispersal modes in dry Mongolian rangelands. Journal of Arid Environments 74, 991-997. doi:10.1016/j.jaridenv.2009.12.002

Bourque, L. B., and Fielder, E. P. (2003). 'How to Conduct Self-administered and Mail Surveys.' (SAGE Publications: London, UK.)

Carr, G. W., Yugovic, J. V., and Robinson, K. E. (1992). 'Environmental Weed Invasions in Victoria: Conservation and Management Implications.' (Department of Conservation and Environment and Ecological Horticulture: Melbourne.)

Ceddia, M. G., Heikkilä, J., and Peltola, J. (2009). Managing invasive alien species with professional and hobby farmers: insights from ecologicaleconomic modelling. Ecological Economics 68, 1366-1374. doi:10.1016/ j.ecolecon.2008.09.006

Coleman, M. J., and Sindel, B. M. (2011). Developing weed management best practice amongst lifestyle farmers. Extension Farming Systems Journal 7, 43-47. www.csu.edu.au

Coleman, M. J., Sindel, B. M., van der Meulen, A. W., and Reeve, I. J. (2011). The risks associated with weed spread in Australia and implications for natural areas. Natural Areas Journal 31, 368-376. doi:10.3375/ 043.031 .0407

Cook, C. (1998). The transmission of serrated tussock (Nassella trichotoma) seeds through the sheep rumen and their viability after ingestion. Plant Protection Quarterly 13, 93.

Coutts, S. R., Hiroyuki, Y., and Buckley, Y. M. (2013). The behaviour of multiple independent managers and ecological traits interact to determine prevalence of weeds. Ecological Applications 23, 523-536. doi: $10.1890 / 12-0599.1$
Coutts-Smith, A., and Downey, P. (2006). 'Impact of Weeds on Threatened Biodiversity in New South Wales.' Technical Series No. 11. (CRC for Australian Weed Management: Adelaide.)

Cowan, T. F., Sindel, B. M., Jessop, R. S., and Browning, J. E. (2007). Mapping the distribution and spread of Nassella trichotoma (serrated tussock) with a view to improving detectability, containment and eradication. Crop Protection 26, 228-231. doi:10.1016/j.cropro.2006. 01.018

CRC for Australian Weed Management (2003). 'Weed Management Guide: Serrated Tussock (Nassella trichotoma).' (CRC for Australian Weed Management and Commonwealth Department of the Environment and Heritage: Adelaide.)

de Vaus, D. A. (1995). 'Surveys in Social Research.' (Allen \& Unwin Pty Ltd: St Leonards, NSW.)

Department of Primary Industries (2004). 'Fact Sheet. Serrated Tussock (Nassella trichotoma).' (NSW Department of Primary Industries: Orange, NSW.)

Fink, A. (2003). 'How to Sample in Surveys.' (Sage Publications Inc.: London, UK.)

Gardener, M. R., Whalley, R. D. B., and Sindel, B. M. (2003). Ecology of Nassella neesiana, Chilean needle grass in pastures on the Northern Tablelands of New South Wales. I. Seed production and dispersal. Australian Journal of Agricultural Research 54, 613-619. doi:10.1071/ AR01075

Greiner, R., Patterson, L., and Miller, O. (2009). Motivations, risk perceptions and adoption of conservation practices by farmers. Agricultural Systems 99, 86-104. doi:10.1016/j.agsy.2008.10.003

Healy, A. J. (1945). 'Nassella Tussock: Field Studies and their Agricultural Significance.' (Department of Scientific and Industrial Research: Wellington, New Zealand.)

Hogan, J. P., and Phillips, C. J. C. (2011). Transmission of weed seed by livestock: a review. Animal Production Science 51, 391-398. doi:10.1071/AN10141

Janzen, D. H. (1984). Dispersal of small seeds by big herbivores: foliage is the fruit. American Naturalist 123, 338-353. doi:10.1086/284208

Klepeis, P., Gill, N., and Chisholm, L. (2009). Emerging amenity landscapes: invasive weeds and land sub-division in rural Australia. Land Use Policy 26, 380-392. doi:10.1016/j.landusepol.2008.04.006

Knowler, D., and Bradshaw, B. (2007). Farmers' adoption of conservation agriculture: a review and synthesis of recent research. Food Policy 32, 25-48. doi:10.1016/j.foodpol.2006.01.003

Kriticos, D. J., Lamoureaux, S., Bourdôt, G. W., and Pettit, W. (2004). Nassella tussock: current and potential distribution in New Zealand. New Zealand Plant Protection 57, 81-88.

Lonsdale, W. M., and Lane, A. M. (1990). Vehicles as vectors of weed seeds in Kakadu National Park. In: 'Proceedings of the 9th Australian Weeds Conference'. (Ed. J. W. Heap.) pp. 134-136. (Crop Science Society of South Australia: Adelaide.)

Lonsdale, W. M., and Lane, A. M. (1994). Tourist vehicles as vectors of weed seeds in Kakadu National Park, Northern Australia. Biological Conservation 69, 277-283. doi:10.1016/0006-3207(94)90427-8

Low Choy, D., and Harding, J. (2008). 'Exploring Agents of Change to Periurban Weed Management: Final Summary Report.' (Land \& Water Australia: Canberra, ACT.)

Marshall, G. R. (2008). 'Community-based Regional Delivery of Natural Resource Management - Building System-wide Capacities to Motivate Voluntary Farmer Adoption of Conservation Practices.' (Rural Industries Research and Development Corporation: Barton, ACT.) Available at: https://rirdc.infoservices.com.au/items/08-175 (accessed 12 May 2015).

Marshall, G. R. (2009). Polycentricity, reciprocity, and farmer adoption of conservation practices under community-based governance. Ecological Economics 68, 1507-1520. doi:10.1016/j.ecolecon.2008. 10.008 
Marshall, G. R. (2010). Governance for a surprising world. In: 'Resilience and Transformation: Preparing Australia for Uncertain Futures'. (Ed. S. Cork.) pp. 49-58. (CSIRO Publishing: Melbourne.)

Marshall, G. R. (2011). What 'community' means for farmer adoption of conservation practices. In: 'Changing Land Management; Adoption of New Practices by Rural Landholders'. (Eds D. J. Pannell and F. Vanclay.) pp. 107-127. (CSIRO Publishing: Melbourne.)

Marshall, G. R., and Stafford Smith, D. M. (2010). Natural resource governance for the drylands of the Murray-Darling Basin. The Rangeland Journal 32, 267-282. doi:10.1071/RJ10020

McLaren, D. A., Ramasamy, S., Lawrie, A. C., Pritchard, G., and Morfe, T. A. (2005). The national serrated tussock survey - impacts and implications of its resistance to the herbicide, flupropanate in Australia. In: 'Proceedings of the Tussock Terminators Research Forum'. pp. 46-52. (Lake Hume Resort: Albury, NSW.) Available at: http://weeds.org.au/ WoNS/Chileanneedlegrass/docs/PROCEEDINGS_Tussock_Terminators. pdf\#page $=50$ (accessed 12 May 2015).

Michelmore, M., Grigulis, K., McLaren, D., and Kritocos, D. (2003). 'Serrated Tussock Managers Fact Pack.' (NSW Agriculture: Orange, NSW.) Available at: www.dpi.nsw.gov.au/_data/assets/pdf_file/0004/ 338872/Recognising-managing-and-preventing-herbicide-resistance-inserrated-tussock.pdf (accessed 12 May 2015).

Northern Inland Regional Weeds Strategy (2010). 'Weed Definitions and FAQs.' (Northern Inland Weeds Advisory Committee: Armidale, NSW.) Available at: www.niwac.org (accessed 12 May 2015).

NSW Department of Primary Industry (2014). Biosecurity legislative framework to protect NSW. Available at: www.dpi.nsw.gov.au/ biosecurity/legislative-review (accessed 9 January 2015).

NSW Scientific Committee (2003). 'Invasion of Native Plant Communities by Exotic Perennial Grasses - Key Threatening Process Declaration.' (NSW Scientific Committee: Hurstville, NSW.)

Office of Environment and Heritage (2012). 'Regional Pest Management Strategy 2012-17, Northern Tablelands Region: a new approach for reducing impacts on native species and park neighbours.' (Office of Environment and Heritage: Sydney, NSW.) Available at: www. environment.nsw.gov.au (accessed 12 May 2015).

Osmond, R., Veebeek, M., McLaren, D. A., Michelmore, M., Wicks, B., Grech, C. J., and Fullerton, P. (2008). 'Serrated Tussock - National Best Practice Manual.' (Department of Primary Industries: Melbourne.) Available at: www.weeds.org.au/WoNS/serratedtussock/docs/stbpmm. pdf (accessed 12 May 2015).

Pannell, D. J., and Wilkinson, R. (2009). Policy mechanism choice for environmental management by non-commercial "lifestyle" rural landholders. Ecological Economics 68, 2679-2687. doi:10.1016/j. ecolecon.2009.05.003

Parsons, W. T., and Cuthbertson, E. G. (2001). 'Noxious Weeds of Australia.' (CSIRO Publishing: Melbourne.)
Sindel, B., Jhorar, O., Reeve, I., and Coleman, M. (2008). 'Best Practice Management for On-ground Property Weed Detection.' (Land and Water Australia: Canberra, ACT.)

Sindel, B. M., Berney, P. J., Marshall, G. R., and Reeve, I. (2013). 'Improving Regional Adoption of Weed Control: A Case Study in the NSW Northern and Southern Tablelands.' RIRDC Publication No. 13/016. (Rural Industries Research and Development Corporation: Canberra, ACT.)

Stanton, R., Pratley, J., and Hudson, D. (2003). Sheep are potential vectors for the spread of canola (Brassica napus) seed. Animal Production Science 43, 535-538. doi:10.1071/EA02046

Taylor, N. J. (1987a). 'Biological Flora and Bibliography of Stipa trichotoma Nees (Poaceae, Nassella tussock).' (Lincoln College: Canterbury, New Zealand.)

Taylor, N. J. (1987b). 'Ecological Aspects of Nassella Tussock (Stipa trichotoma).' (Botany Division, Department of Scientific Research: Lincoln, New Zealand.)

Theoharides, K. A., and Dukes, J. S. (2007). Plant invasion across space and time: factors affecting non-indigenous species success during four stages of invasion. New Phytologist 176, 256-273. doi:10.1111/j.14698137.2007.02207.x

Thorp, J. R., and Lynch, R. (2000). 'The Determination of Weeds of National Significance.' (National Weeds Strategy Executive Committee: Launceston, Tas.)

Vanclay, F. (2004). Social principles for agricultural extension to assist in the promotion of natural resource management. Australian Journal of Experimental Agriculture 44, 213-222. doi:10.1071/EA02139

Wace, N. (1977). Assessment of dispersal of plant species: the car-borne flora in Canberra. Proceedings of the Ecological Society of Australia 10, $167-186$.

Watt, M. S., Kriticos, D. J., Lamoureaux, S. L., and Bourdôt, G. W. (2011). Climate change and the potential global distribution of serrated tussock (Nassella trichotoma). Weed Science 59, 538-545. doi:10.1614/ WS-D-11-00032.1

Wilson, B. R., and Lonergan, V. E. (2013). Land-use and historical management effects on soil organic carbon in grazing systems on the Northern Tablelands of New South Wales. Soil Research 51, 668-679. doi: $10.1071 /$ SR12376

Wilson, R. S., Tucker, M. A., Hooker, N. H., LeJeune, J. T., and Doohan, D. (2008). Perceptions and beliefs about weed management: perspectives of Ohio grain and produce farmers. Weed Technology 22, 339-350. doi:10.1614/WT-07-143.1

Wilson, R. S., Hooker, N., Tucker, M., LeJeune, J., and Doohan, D. (2009). Targeting the farmer decision making process: a pathway to increased adoption of integrated weed management. Crop Protection 28, 756-764. doi:10.1016/j.cropro.2009.05.013 
Appendix 1. Cover letter and questionnaire

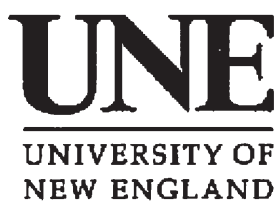

School of Environmental and Rural Science

Armidale NSW 2351 Australia

Telephone: 61267732323

Facsimile: 61267732769

Email: erseune.eduau

NEW ENGLAND

Web: www.une.edu.au/ers

Professor Brian Sindel

Department of Agronomy and Soil Science

Stopping the spread of serrated tussock

Dear Landholder

It is likely that you have heard of serrated tussock (Nassella trichotoma), which is one of twenty Weeds of National Significance (WONS). WONS species are so important that their management is a national priority. Serrated tussock is a significant problem for livestock producers because it reduces the value of grazing land due to its extremely low forage value. Research has shown that sheep which graze pastures consisting mostly of serrated tussock will lose condition and die unless their diet is supplemented with more nutritious feed. The weed has already cost Australian farmers millions of dollars in lost production and control. Once the weed becomes established, its control is very difficult and costly. For this reason, experts on the species are encouraging landholders to prevent the species becoming established in the first place. In other words, where serrated tussock is concerned, prevention is definitely better than cure.

Annie Schneider, a PhD student in the School of Environmental and Rural Science at the University of New England, is surveying landholders in the Northern Tablelands of New South Wales to discover how serrated tussock is spreading in this region. The survey also examines the methods that landholders, like yourself, are using to prevent further spread. We plan to communicate the results of this survey to a wide audience including landholders, scientists, and government agencies. We anticipate that this will improve prevention strategies for serrated tussock, thereby minimising the number of landholders affected by this weed in the future.

We would be most grateful for your participation, whether you have serrated tussock on your property or not. If you are aged 18 years or older, and own or manage rural land, please complete the enclosed survey and return it using the self-addressed, postage-paid envelope provided. Please understand that your participation is purely voluntary, and your identity will remain anonymous. If you wish to know more about the survey, please call Annie on 0267733075.

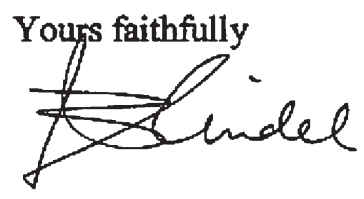

\section{Professor Brian Sindel}

Department of Agronomy and Soil Science

University of New England 


\section{STOPPING SERRATED TUSSOCK IN ITS TRACKS}

\section{SURVEY INSTRUCTIONS}

This survey is intended for persons aged 18 years and older who own or manage rural land.

If you own or manage more than one rural property. please choose the LARGEST of them and answer this survey in relation to that property.

Additional comments can be written on the last page of this survey.

For each question, please tick the box for the most appropriate answer or write your answer in the space provided.

\section{SECTION ONE: PROPERTY INFORMATION}

1. What is the main purpose for which your land is used?

$\square$ Rural retreat

D Hobby farm

Commercial livestock production

- Commercial cropping

- Mixed livestock and cropping

$\square$ Commercial horticulture

$\square$ Other (please specity)
2. What is the approximate distance and direction to your property from the nearest town?

Distance:

$(\mathrm{km})$

Direction (please circle)

N. S, E, W, NE. NW, SE. SW of

Name of town:

\section{SECTION TWO: KNOWLEGE OF SERRATED TUSSOCK}

1. Do you consider serrated tussock a serious weed that should be controlled?

$\square$ Yes

$\square$ No

U Undecided

2. What would you do if you knew that someone in your district had serrated tussock growing on their land but was not controlling it?

- Talk 10 the land-owner in question

$\square$ Tell the local weeds authority

$\square$ Nothing

Other (please specity)
3. Are you reasonably confident that you are able to identify serrated tussock?

$\square$ Yes

No

4. Does serrated tussock occur in your local area?

$\square$ Yes

$\square$ No

$\square$ Unsure

5. Have you ever found serrated tussock on your property?

$\square$ Yes (please answer sections Three and Four)

$\square$ No (please go to section Four)

$\square$ Unsure (please go to section Four) 


\section{SECTION THREE: PROPERTIES WHERE SERRATED TUSSOCK IS PRESENT}

1. How do you think serrated tussock was first Introduced to your property? Please tlck only ONE answer.

$\square$ Contaminated hay

$\square$ Contaminated grain

Contaminated seed (i.e. for sowing pasture or crops)

$\square$ Contaminated building materials or landscaping supplies (e.g. wood, soil, gravel)

- Contaminated livestock (i.e. carrying seed internally, or externally e.g. in fleece)

$\square$ Contaminated wild-life (i.e. carrying seed internally, or externally e.g. in fur)

$\square$ Blown in by the wind (e.g. from an up-wind infestation)

Water (e.g. it first appeared after a flood or along a river bank)

$\square$ Brought in on farm machinery

$\square$ Brought in machinery used for construction or maintenance of utilities (e.g. power lines, roads, telephone lines)

Brought in on a passenger vehicle

U Unknown

Other (please specify)

2. In the lefthand column of the table below, methods are listed that can reduce the spread and establishment of serrated tussock WITHIN your property. For every method, please tick the box in only one column, to indicate which statement is most true for you.

\begin{tabular}{|l|c|c|c|}
\hline \multicolumn{1}{|c|}{ Method } & $\begin{array}{c}\text { Not } \\
\text { relevant }\end{array}$ & $\begin{array}{l}\text { I do } \\
\text { this }\end{array}$ & $\begin{array}{c}\text { I don't } \\
\text { do this }\end{array}$ \\
\hline $\begin{array}{l}\text { Shear un-shom sheep that have been in areas where serrated tussock is in } \\
\text { seed before moving them to un-infested areas, to get rid of seed in the fleece }\end{array}$ & $\square$ & $\square$ & $\square$ \\
\hline $\begin{array}{l}\text { Grazing animals that have been in areas where serrated tussock is in seed are } \\
\text { kept in holding yards for . (specific number) days, on average, so that } \\
\text { they can excrete the seeds before entering un-infested paddocks }\end{array}$ & $\square$ & $\square$ & $\square$ \\
\hline Keep grazing animals out of pastures where serrated tussock is in seed & $\square$ & $\square$ & $\square$ \\
\hline Keep vehicles and machinery out of areas where serrated tussock is in seed & $\square$ & $\square$ & $\square$ \\
\hline $\begin{array}{l}\text { Clean equipment, machinery and vehicles that have been used in areas where } \\
\text { serrated tussock is in seed, before using them in un-infested areas }\end{array}$ & $\square$ & $\square$ & $\square$ \\
\hline Avoid letting serrated tussock set seed (e.g. chip them out before spring) & $\square$ & $\square$ & $\square$ \\
\hline Follow-up control in areas where serrated tussock has previously been treated & $\square$ & $\square$ & $\square$ \\
\hline Collect and appropriately dispose of serrated tussock seed-heads & $\square$ & $\square$ & $\square$ \\
\hline Regularty inspect land down-wind of existing serrated tussock infestations & $\square$ & $\square$ & $\square$ \\
\hline Create seed-traps (e.g. treerows, mesh fences) to prevent wind-borne spread & $\square$ & $\square$ & $\square$ \\
\hline Other (please specify) & $\square$ & $\square$ & $\square$ \\
\hline
\end{tabular}




\section{SECTION FOUR: KEEPING YOUR PROPERTY FREE OF SERRATED TUSSOCK}

1. Regularly inspecting your property for weeds can help to ensure that serrated tussock can be discovered and controlled at an early stage. Please indicate which of the following areas you inspect for weeds on a regular basis (i.e. at least once every 12 months). Please tick all answers that apply to you.

$\square$ Natural water-courses (e.g. streams, rivers, creeks)

$\square$ Livestock watering areas (dams, troughs)

$\square$ Roads and traffic areas

Boundaries and fence lines

Livestock camps

$\square$ Remote and difficult-to-access areas

Slock yards, and areas around wool sheds and other farm struclures

Areas where machinery from off-farm has been used

$\square$ Pastures used for livestock grazing (includes horses and other domestic grazing animals)

$\square$ Cultivated land

$\square$ Areas downwind of serrated tussock infestations (e.g. on a neighbours property)

$\square$ Other (please specify)

2. In the left-hand column of the table below, methods are listed that can reduce the amount of weed seeds that enter your land, including serrated tussock. For every method, please tick the box in only one column, to indicate which statement is most true for you.

\begin{tabular}{|c|c|c|c|}
\hline Method & $\begin{array}{l}\text { Not } \\
\text { relevant }\end{array}$ & $\begin{array}{l}\text { I do } \\
\text { this }\end{array}$ & $\begin{array}{l}\text { I don't } \\
\text { do this }\end{array}$ \\
\hline $\begin{array}{l}\text { Only use farm contractors that are accredited in weed hygiene (or only hire } \\
\text { contractors that you know are careful not lo spread weeds) }\end{array}$ & $\square$ & $\square$ & $\square$ \\
\hline $\begin{array}{l}\text { Vehicles, machinery and equipment from off-fam that are likely to carry weed } \\
\text { seeds must be property cleaned before entering the paddocks }\end{array}$ & $\square$ & $\square$ & $\square$ \\
\hline $\begin{array}{l}\text { If it is known that a vehicle, machine or item of equipment has been used in an } \\
\text { area infested with serrated tussock, it is not pemitted to enter my land }\end{array}$ & $\square$ & $\square$ & $\square$ \\
\hline $\begin{array}{l}\text { Unknown grasses are identified before they become widespread (e.g. by } \\
\text { consulting a weed expert, a weed book, website, etc.) }\end{array}$ & $\square$ & $\square$ & $\square$ \\
\hline Only purchase certified seed (with minimum weed content) for sowing & $\square$ & $\square$ & $\square$ \\
\hline Feed-out bought hay or grain in spots where weeds are regularly controlled & $\square$ & $\square$ & $\square$ \\
\hline $\begin{array}{l}\text { Newly bought livestock are kept in holding yards for (specific number) } \\
\text { days, on average, so that they can excrete weed seeds before enlering other } \\
\text { paddocks }\end{array}$ & $\square$ & $\square$ & $\square$ \\
\hline $\begin{array}{l}\text { Before moving sheep into grazing pastures, newly bought, unshom sheep are } \\
\text { shom to remove weed seeds caught in the fleece }\end{array}$ & $\square$ & $\square$ & $\square$ \\
\hline Other (please specify) & $\square$ & $\square$ & $\square$ \\
\hline
\end{tabular}

Thank you for your participation! Please return the survey to A. Schneider, Agronomy and Soil Science, University of New England, Armidale NSW 2351 


\section{Additional comments:}

